\title{
Analysing Islamic Bank Efficiency in Malaysia Using the Standard and Alternative Approaches to Data Envelopment Analysis
}

\author{
*Izah Mohd Tahir ${ }^{1}$, Ahmad Rizal Razali ${ }^{1}$, Sudin Haron² \\ 1University Sultan Zainal Abidin, Malaysia \\ ${ }^{2}$ Kuala Lumpur Business School, Malaysia \\ *izah@unisza.edu.my
}

\begin{abstract}
The purpose of this paper is to analyse the efficiency of Islamic banks in Malaysia using both the standard approach and the alternative approach to Data Envelopment Analysis (DEA). The standard approach relies on linear averages of outputs and inputs to measure efficiency whereas the alternative approach uses nonlinear averages. Both approaches are tested on 14 Islamic banks in Malaysia for the three-year period, 2008 to 2010. Our overall results for the three years suggest that, the inefficiency level among these banks using the standard approach (SDEA) is much higher than using the alternative approach (ADEA). Implications and future research are also discussed.
\end{abstract}

Keywords: Efficiency, Data Envelopment Analysis (DEA), standard approach, alternative approach, Islamic banks, Malaysia

\section{Introduction}

Islamic banking today has become a practical reality and accepted worldwide. The industry has transformed from an infant industry in the 1970s to one of the most viable and efficient alternative models of financial intermediation. It has consistently grown into double-digit with a presence in more than 100 countries. It is estimated that total financial assets of the industry now exceed US $\$ 1$ trillion. World economic powers such as Great Britain, France, Germany, and even Russia are considering amending their financial laws with the purpose of accommodating the establishment of Islamic banks within their financial system. The integration of Islamic finance into the global economy is discernible by the growing awareness among the population and demand for investing in accordance with shariah principles, progress in developing a regulatory framework and enhanced international linkages. However, the success of Islamic banking brings forth new challenges to the industry. These include lack of standard financial contracts and products, illiquidity issues, risks mitigation in the operational aspects and financing portfolios, and co-operation among the players within the industry. These successes and challenges facing Islamic financial institutions have been widely documented. Nonetheless, there is still an acute dearth of literature which covers concepts and applications of Islamic banking worldwide as well as provides comprehensive illustration of all major aspects of Islamic finance and banking on a more global scale. Having kept a close watch on the developments in Islamic finance and banking over the last two decades, we acknowledge that there are many issues yet to be resolved. Among the major areas that need in-depth study are productivity, efficiency and performance measurement.

In Malaysia, the study on bank efficiency especially in Islamic banking is still considered scarce. Examples of these studies are Sufian (2007), Kamaruddin et al. (2008) and Tahir et al. (2011). These studies were done using the standard approach to Data Envelopment Analysis. As far as we are aware, studies using the alternative approach to Data Envelopment Analysis were not available. Therefore this paper aims to compare the standard approach and the alternative approaches to DEA using sample data from Islamic banks in Malaysia for the period 2008 to 2010.The aim of this paper is analyse the efficiency of Islamic banks in Malaysia using both the conventional and the alternative approach to Data Envelopment Analysis (DEA). This paper is structured as follows: Section 2 will briefly discuss the relevant literature on bank efficiency studies followed by Methodology and Data in Section 3. Empirical results are presented in Section 4 followed by conclusions and future research in Section 5.

\section{Literature Review}

According to Berger and Humphrey (1997) in their survey of 130 studies on efficiency analyses found that majority of these studies were done in the US banking industry. Despite the fact that efficiency 
studies are well researched area in the developed countries like USA and Europe, there are still limited studies focussing on the efficiency of Islamic banking. In the Islamic banking institutions, efficiency studies are still scarce. Several studies in Islamic banking focus on assessing the performance in terms of profitability and determinants of bank performance (Samad and Hassan, 1999; Bashir, 2001; Samad2004; Haron and Azmi, 2004). In terms of efficiency using DEA, studies in Islamic banking were done by for example, Sufian (2007), Kamaruddin et al. (2008), and Tahir et al. (2011). Sufian (2007) study the efficiency of domestic and foreign Islamic banks in Malaysia for the period 2001 to 2004 using DEA. The study found that domestic Islamic banks are more efficient than foreign domestic banks and suggest that these inefficient banks were operating at the wrong scale of operations. In another study by Kamaruddin et al (2008) on Islamic banks in Malaysia for the period 1998 to 2004, found that Islamic banks in Malaysia ) were relatively more efficient at controlling costs than at generating profits.

Tahir et al. (2011) study Islamic bank efficiency in four regions; Africa, the Far East and Central Asia, Europe and the Middle East during 2003 to 2008. Their results suggest that the mean efficiency of these banks have declined from $74.6 \%$ in 2003 to $54.4 \%$ in 2008 and that pure technical efficiency has largely resulted in the inefficiency of Islamic banks. Their results also indicate that there are significant differences in terms of the efficiency between sizes but not between regions. Aik and Tan (2012) investigate the cost and profit efficiency of the full-fledged Islamic banks and Islamic windows in Malaysian from 2002 to 2008 using DEA. Their results show that the full-fledged Islamic banks are relatively more efficient than Islamic windows and that Malaysian Islamic bank are more efficient in generating profits than controlling their costs. All the research mentioned above employed the standard DEA approach. As far as we are aware only one research has focussed on the alternative approach to DEA. The study was done by Shirvani, Taj and Mirshab (2011). The authors use the ADEA with nonlinear averages to study efficiency of 27 Turkish banks for 2008. The findings of their study show that "the extent of inefficiency among these banks is much smaller than implied by the use of the more standard approach" (page 9).

\section{Methodology}

Standard DEA: The main objective of DEA is to determine which firms are operating on their efficient frontier and which firms are not. If the firm's input-output combination lies on the DEA frontier, the firm is considered efficient; and the firm is considered inefficient if the firm's input-output combination lies inside the frontier. Consider a general situation where we have $\mathrm{n}$ decision making units (DMUs) and each consumes the same $m$ inputs to produce the same s outputs. Precisely, DMU $\mathrm{Duses}_{i j}(I=1,2,3 \ldots, \mathrm{m})$ of input $i$ to produce $y_{r j}(r=1,2 \ldots \ldots, s)$ of output $r$ assuming that $x_{i j}>0$ and $y_{r j}>0$ (Seiford and Thrall, 1990). The specific DMU being evaluated has to solve the following optimization problem:

$\operatorname{Maxh}_{0}=\sum_{r=1}^{s} u_{r} y_{r o} / \sum_{i=1}^{m} v_{r} x_{i 0}$

subject to the constraints:

$\sum_{r=1}^{s} u_{r} y_{r j} / \sum_{i=1}^{m} v_{i} x_{i j} \leq 1, u_{r} \geq 0, v_{i} \geq 0$

For $i=1,2, \ldots ., m ; r=1,2, \ldots . S ; j=1,2, \ldots ., n$. Where $\mathrm{h}_{\mathrm{o}}$ is the ratio of virtual outputs to virtual inputs, the $u_{r}^{\prime} \mathrm{s}$ and the $v_{j}^{\prime}$ s are the variables an the $y_{r o}$ 'sand the $x_{j o}$ 's are the observed output and input values of the DMU to be evaluated. A set of normalizing constraints guarantees that no DMU, including the one evaluated, can obtain an efficiency score that exceeds unity. Thus, DEA establishes a benchmark efficiency score of unity that no individual firm can exceed. If the efficiency score $h_{o}=1, \mathrm{DMU}_{\mathrm{o}}$ satisfies the necessary condition to be DEA efficient; otherwise it is DEA inefficient.

Alternative DEA: However, according to Shirvani et al. (2011, page 6)," the use of linear weighted averages of outputs and inputs renders the efficiency ratios nonlinear and thus, necessitates the constraint that the denominations of these ratios are all equal to one". To overcome this, the standard DEA is slightly modified with the use of nonlinear weighted averages of outputs and inputs. In other words, instead of using the normal values, we convert all the inputs and inputs in logarithm. 
Data: Data for this study is taken from Bankscope database. The data is for 14 Islamic banks of which 9 are local Islamic banks and 5 are foreign Islamic banks. The list of banks is in Appendix1. The period chosen is for the three-year period, 2008 to 2010.

\section{Empirical Results}

Standard DEA: The choice of inputs and outputs to be employed in estimating the efficiency scores are voluminous. However, in this study, we are not going to discuss on this issue. In this study we adopt the intermediation approach in which banks provides loans and accepting deposits from the customers. Thus, the outputs for our model are total loans and other earning assets while the inputs are total customer deposits and fixed assets. The data employed in this study are for 14 Islamic banks for the period 20082010 and taken from Banskcope database. All the financial data are MYR thousand. The data is presented along with the efficiency measures are presented in Tables 1 to 3. From the results in Table 1 we can see that there are 6 banks that have efficiency scores of $100 \%$ (Banks 2, 3, 5, 8, 13 and 14). In contrast, Bank 11,10 and 4 have the lowest efficiency scores of 29\%, 49\% and 55\% respectively. These banks are the least efficient banks in our sample. The results also indicate that 8 banks could make substantial improvements in their performance.

Table 1: Outputs, Inputs and Standard DEA Efficiency, 2008

\begin{tabular}{llllll}
\hline & Outputs ('000 MYR) & \multicolumn{3}{l}{ Inputs ('000 MYR) } \\
Total \\
DMUs & Total Loans & $\begin{array}{l}\text { Other Earning } \\
\text { Assets }\end{array}$ & $\begin{array}{l}\text { Customer } \\
\text { Deposits }\end{array}$ & Fixed Assets & $\begin{array}{l}\text { Standard DEA } \\
\text { Efficiency }\end{array}$ \\
\hline 1 & $2,494,000$ & $1,073,200$ & $4,252,100$ & 3,200 & 0.76 \\
2 & $2,073,100$ & 327,300 & $1,755,700$ & 200 & 1.00 \\
3 & $8,363,400$ & 831,100 & $6,916,100$ & 400 & 1.00 \\
4 & $10,458,800$ & $3,846,900$ & $20,754,300$ & 142,400 & 0.55 \\
5 & $6,145,489$ & $5,843,767$ & $13,661,386$ & 3,855 & 1.00 \\
6 & $4,860,349$ & 353,004 & $4,735,142$ & 2,162 & 0.81 \\
7 & $4,332,100$ & $1,835,400$ & $6,208,100$ & 1,800 & 0.91 \\
8 & $12,089,900$ & 782,700 & $9,622,300$ & 400 & 1.00 \\
9 & $5,542,300$ & $2,282,500$ & $7,347,300$ & 19,400 & 0.92 \\
10 & $2,914,359$ & 174,721 & $4,016,941$ & 68,478 & 0.49 \\
11 & 259,700 & 79,200 & 968,100 & 5,300 & 0.26 \\
12 & $3,000,800$ & 833,300 & $3,244,300$ & 2,500 & 0.96 \\
13 & $6,411,500$ & 984,500 & $4,293,300$ & 44,800 & 1.00 \\
14 & $2,199,400$ & 837,600 & $2,691,000$ & 1,900 & 1.00 \\
Average & & & & & $\mathbf{0 . 8 3}$ \\
\hline
\end{tabular}

Table 2: Outputs, Inputs and Standard DEA Efficiency 2009

\begin{tabular}{llllll}
\hline & Outputs ('000 MYR) & \multicolumn{3}{l}{ Inputs ('000 MYR) } & Standard DEA \\
DMUs & Total Loans & $\begin{array}{l}\text { Other Earning } \\
\text { Assets }\end{array}$ & $\begin{array}{l}\text { Customer } \\
\text { Deposits }\end{array}$ & Fixed Assets & \begin{tabular}{l} 
Efficiency \\
\hline 1
\end{tabular} \\
& $2,951,600$ & $1,386,100$ & $4,627,300$ & 4,200 & 0.86 \\
2 & $2,383,000$ & 458,600 & $2,617,700$ & 700 & 0.86 \\
3 & $10,076,000$ & 775,100 & $10,155,100$ & 400 & 0.89 \\
4 & $10,711,000$ & $8,915,900$ & $25,204,600$ & 142,100 & 1.00 \\
5 & $16,394,842$ & $6,087,714$ & $17,496,497$ & 2,625 & 1.00 \\
6 & $4,777,946$ & 520,637 & $4,833,735$ & 2,623 & 0.86 \\
7 & $3,919,400$ & $2,730,800$ & $7,979,900$ & 1,800 & 0.98 \\
8 & $14,590,200$ & $1,359,500$ & $13,073,700$ & 500 & 1.00 \\
9 & $6,086,100$ & $2,573,500$ & $8,127,800$ & 23,100 & 0.91 \\
10 & $3,883,036$ & 175,983 & $4,431,772$ & 61,286 & 0.50 \\
11 & 686,400 & 139,700 & $1,079,300$ & 5,400 & 0.45 \\
12 & $3,253,000$ & 511,600 & $2,472,400$ & 7,500 & 1.00 \\
13 & $7,486,900$ & $1,267,600$ & $4,255,100$ & 37,000 & 1.00 \\
14 & $2,190,100$ & $1,174,500$ & $3,721,900$ & 6,500 & 0.90 \\
Average & & & & & $\mathbf{0 . 8 7}$ \\
\hline
\end{tabular}


The results in Table 2 show that 5 banks that have efficiency scores of 100\% (Banks 4, 5, 8, 12 and 13). Two banks are the least efficient banks in the sample for 2009 that is Banks 11 and 10 (45\% and 50\% respectively). The results further indicate that 9 banks in the sample could make improvements in their productivity. In Table 3, we can see that the number of banks in the sample that have productivity ratings of $100 \%$ is 6 . These banks are Banks 3, 4, 5, 7, 8 and 12. The least efficient bank is Bank 11 and 10 with efficiency scores of $71 \%$ and $75 \%$ respectively. Thus, from the table we can see that 8 banks in the sample can improve their productivity during the period.

Table 3: Outputs, Inputs and Standard DEA Efficiency 2010

\begin{tabular}{llllll}
\hline & Outputs ('000 MYR) & \multicolumn{3}{l}{$\begin{array}{l}\text { Inputs ('000 MYR) } \\
\text { Total } \\
\text { Customer } \\
\text { Deposits }\end{array}$} & Fixed Assets \\
& Total Loans & Assets & $\begin{array}{l}\text { Standard DEA } \\
\text { Efficiency }\end{array}$ \\
\hline 1 & $3,644,200$ & $1,337,300$ & $5,533,500$ & 2,100 & 0.77 \\
2 & $3,474,900$ & 586,100 & $4,027,800$ & 600 & 0.81 \\
3 & $12,008,300$ & $1,412,300$ & $13,398,000$ & 300 & 1.00 \\
4 & $12,284,700$ & $15,655,400$ & $26,866,600$ & 181,500 & 1.00 \\
5 & $22,757,750$ & $4,998,176$ & $22,677,955$ & 1,862 & 1.00 \\
6 & $5,444,415$ & $1,304,432$ & $6,025,709$ & 3,801 & 0.89 \\
7 & $4,227,700$ & $3,633,800$ & $7,731,600$ & 2,000 & 1.00 \\
8 & $16,589,600$ & $2,441,900$ & $15,306,700$ & 1,500 & 1.00 \\
9 & $9,036,000$ & $3,120,900$ & $9,946,600$ & 21,500 & 0.91 \\
10 & $4,280,314$ & 392,501 & $3,907,946$ & 38,215 & 0.75 \\
11 & 768,400 & 339,200 & $1,125,700$ & 4,400 & 0.71 \\
12 & $4,748,800$ & 478,700 & $3,782,500$ & 16,400 & 0.93 \\
13 & $6,603,300$ & $1,567,800$ & $4,546,500$ & 27,300 & 1.00 \\
14 & $2,555,700$ & $1,123,800$ & $2,920,900$ & 7,800 & 0.93 \\
Average & & & & & $\mathbf{0 . 9 1}$ \\
\hline
\end{tabular}

As a conclusion, the three tables (Table 1 to 3 ) show that the numbers of banks that are constantly efficient throughout the three-year period are three banks (Bank 5, 8 and 13). Five banks (Banks 4, 6, 7, 10 , and 11) have improved their productivity during the period. Further investigations show that 9 banks in the sample could make substantial productivity improvements.

Alternative DEA: To compare with the new approach or the alternative approach of DEA (ADEA), we present the results in Tables 4 to 6 . We use the same sample banks in the analysis. The results in Table 4 show that the numbers of banks with the efficiency scores of $100 \%$ are 9 . These are Banks number 2, 3, 5, $7,8,912,13$ and 14 . The other five banks could make productivity improvements during this period.

Table 4: Outputs, Inputs and Alternative DEA Efficiency, 2008

\begin{tabular}{|c|c|c|c|c|c|}
\hline & Outputs ('00 & & Inputs ('00 & & \\
\hline DMUs & Total Loans & $\begin{array}{l}\text { Other Earning } \\
\text { Assets }\end{array}$ & $\begin{array}{l}\text { Total } \\
\text { Customer } \\
\text { Deposits }\end{array}$ & Fixed Assets & $\begin{array}{l}\text { Alternative } \\
\text { DEA Efficiency }\end{array}$ \\
\hline 1 & 14.73 & 13.89 & 15.26 & 8.07 & 0.98 \\
\hline 2 & 14.54 & 12.70 & 14.38 & 5.30 & 1.00 \\
\hline 3 & 15.94 & 13.63 & 15.75 & 5.99 & 1.00 \\
\hline 4 & 16.16 & 15.16 & 16.85 & 11.87 & 0.97 \\
\hline 5 & 15.63 & 15.58 & 16.43 & 8.26 & 1.00 \\
\hline 6 & 15.40 & 12.77 & 15.37 & 7.68 & 0.98 \\
\hline 7 & 15.28 & 14.42 & 15.64 & 7.50 & 1.00 \\
\hline 8 & 16.31 & 13.57 & 16.08 & 5.99 & 1.00 \\
\hline 9 & 15.53 & 14.64 & 15.81 & 9.87 & 1.00 \\
\hline 10 & 14.89 & 12.07 & 15.21 & 11.13 & 0.95 \\
\hline 11 & 12.47 & 11.28 & 13.78 & 8.58 & 0.90 \\
\hline 12 & 14.91 & 13.63 & 14.99 & 7.82 & 1.00 \\
\hline 13 & 15.67 & 13.80 & 15.27 & 10.71 & 1.00 \\
\hline & 14.60 & 13.64 & 14.81 & 7.55 & 1.00 \\
\hline Average & & & & & 0.98 \\
\hline
\end{tabular}


The results in Table 5 show that the number of banks with $100 \%$ efficiency has declined to 6 banks. These are Bank 3, 4, 5, 7, 8 and 13. 8 banks could make improvements during the period. The least efficient during 2009 is Bank 11 with 45\% efficiency score. This indicates that Bank 11 has wasted their inputs of $55 \%$.

Table 5: Outputs, Inputs and Alternative DEA Efficiency, 2009

\begin{tabular}{|c|c|c|c|c|c|}
\hline \multirow{2}{*}{ DMUs } & \multicolumn{2}{|l|}{ Outputs ('000 MYR) } & \multicolumn{3}{|c|}{ Inputs ('000 MYR) } \\
\hline & Total Loans & $\begin{array}{l}\text { Other Earning } \\
\text { Assets }\end{array}$ & $\begin{array}{l}\text { Total } \\
\text { Customer } \\
\text { Deposits }\end{array}$ & Fixed Assets & $\begin{array}{l}\text { Alternative } \\
\text { DEA Efficiency }\end{array}$ \\
\hline 1 & 14.90 & 14.14 & 15.35 & 8.34 & 0.98 \\
\hline 2 & 14.68 & 13.04 & 14.78 & 6.55 & 0.99 \\
\hline 3 & 16.13 & 13.56 & 16.13 & 5.99 & 1.00 \\
\hline 4 & 16.19 & 16.00 & 17.04 & 11.86 & 1.00 \\
\hline 5 & 16.61 & 15.62 & 16.68 & 7.87 & 1.00 \\
\hline 6 & 15.38 & 13.16 & 15.39 & 7.87 & 0.98 \\
\hline 7 & 15.18 & 14.82 & 15.89 & 7.50 & 1.00 \\
\hline 8 & 16.50 & 14.12 & 16.39 & 6.21 & 1.00 \\
\hline 9 & 15.62 & 14.76 & 15.91 & 10.05 & 0.99 \\
\hline 10 & 15.17 & 12.08 & 15.30 & 11.02 & 0.96 \\
\hline 11 & 13.44 & 11.85 & 13.89 & 8.59 & 0.94 \\
\hline 12 & 15.00 & 13.15 & 14.72 & 8.92 & 0.99 \\
\hline 13 & 15.83 & 14.05 & 15.26 & 10.52 & 1.00 \\
\hline 14 & 14.60 & 13.98 & 15.13 & 8.78 & 0.99 \\
\hline Average & & & & & 0.99 \\
\hline
\end{tabular}

Further investigation for the period 2010 shows that the numbers of banks that are $100 \%$ efficient remain the same as in 2009 that is 6 banks. These banks are Banks 3, 4, 5, 7, 8 and 13. These are the same banks that are efficient in 2009. As a conclusion, the results from the three tables (Tables 4 to 6) show that the numbers of banks that are constantly efficient throughout the three-year period are four banks (Banks 3, 5, 8, and 13). Only 1 bank (Bank 4) has improved its productivity during the period. Further investigations show that 10 banks in the sample could make substantial productivity improvements.

Table 6: Outputs, Inputs and Alternative DEA Efficiency, 2010

\begin{tabular}{|c|c|c|c|c|c|}
\hline \multirow[b]{2}{*}{ DMUs } & \multicolumn{2}{|l|}{ Outputs ('000 MYR) } & \multicolumn{3}{|c|}{ Inputs ('000 MYR) } \\
\hline & Total Loans & $\begin{array}{l}\text { Other Earning } \\
\text { Assets }\end{array}$ & $\begin{array}{l}\text { Total } \\
\text { Customer } \\
\text { Deposits } \\
\end{array}$ & Fixed Assets & $\begin{array}{l}\text { Alternative } \\
\text { DEA Efficiency }\end{array}$ \\
\hline 1 & 15.11 & 14.11 & 15.53 & 7.65 & 0.98 \\
\hline 2 & 15.06 & 13.28 & 15.21 & 6.40 & 0.99 \\
\hline 3 & 16.30 & 14.16 & 16.41 & 5.70 & 1.00 \\
\hline 4 & 16.32 & 16.57 & 17.11 & 12.11 & 1.00 \\
\hline 5 & 16.94 & 15.42 & 16.94 & 7.53 & 1.00 \\
\hline 6 & 15.51 & 14.08 & 15.61 & 8.24 & 0.98 \\
\hline 7 & 15.26 & 15.11 & 15.86 & 7.60 & 1.00 \\
\hline 8 & 16.62 & 14.71 & 16.54 & 7.31 & 1.00 \\
\hline 9 & 16.02 & 14.95 & 16.11 & 9.98 & 0.99 \\
\hline 10 & 15.27 & 12.88 & 15.18 & 10.55 & 0.98 \\
\hline 11 & 13.55 & 12.73 & 13.93 & 8.39 & 0.97 \\
\hline 12 & 15.37 & 13.08 & 15.15 & 9.71 & 0.99 \\
\hline 13 & 15.70 & 14.27 & 15.33 & 10.21 & 1.00 \\
\hline 14 & 14.75 & 13.93 & 14.89 & 8.96 & 0.99 \\
\hline Average & & & & & 0.99 \\
\hline
\end{tabular}

Table 7 present the comparison between using DEA and ADEA. The results show that by applying the new approach, the level of efficiency is relatively higher. This supports the findings by Shirvani et al (2011). Three banks in the sample i.e. Banks 5, 8 and 13 were efficient under both approaches. We also apply the parametric and non-parametric test to test whether there are any significant differences using the two methods. The results show that as an overall, there is a significant difference using the two methods. In 
other words, our results show that using the alternative method relatively produces lower level of inefficiency.

Table 7: Comparison SDEA and ADEA

\begin{tabular}{|c|c|c|c|c|c|c|}
\hline \multirow[b]{2}{*}{ DMUs } & \multicolumn{2}{|l|}{2008} & \multicolumn{2}{|l|}{2009} & \multicolumn{2}{|l|}{2010} \\
\hline & SDEA & ADEA & SDEA & ADEA & SDEA & ADEA \\
\hline 1 & 0.76 & 0.98 & 0.86 & 0.98 & 0.77 & 0.98 \\
\hline 2 & 1.00 & 1.00 & 0.86 & 0.99 & 0.81 & 0.99 \\
\hline 3 & 1.00 & 1.00 & 0.89 & 1.00 & 1.00 & 1.00 \\
\hline 4 & 0.55 & 0.97 & 1.00 & 1.00 & 1.00 & 1.00 \\
\hline 5 & 1.00 & 1.00 & 1.00 & 1.00 & 1.00 & 1.00 \\
\hline 6 & 0.81 & 0.98 & 0.86 & 0.98 & 0.89 & 0.98 \\
\hline 7 & 0.91 & 1.00 & 0.98 & 1.00 & 1.00 & 1.00 \\
\hline 8 & 1.00 & 1.00 & 1.00 & 1.00 & 1.00 & 1.00 \\
\hline 9 & 0.92 & 1.00 & 0.91 & 0.99 & 0.91 & 0.99 \\
\hline 10 & 0.49 & 0.95 & 0.50 & 0.96 & 0.75 & 0.98 \\
\hline 11 & 0.26 & 0.90 & 0.45 & 0.94 & 0.71 & 0.97 \\
\hline 12 & 0.96 & 1.00 & 1.00 & 0.99 & 0.93 & 0.99 \\
\hline 13 & 1.00 & 1.00 & 1.00 & 1.00 & 1.00 & 1.00 \\
\hline 14 & 1.00 & 1.00 & 0.90 & 0.99 & 0.93 & 0.99 \\
\hline AVG & 0.83 & 0.98 & 0.87 & 0.99 & 0.91 & 0.99 \\
\hline \multicolumn{7}{|c|}{ Summary of Parametric and Non-Parametric Tests } \\
\hline ANOVA & 129.476 & .000 & 43.852 & .000 & 19.270 & .000 \\
\hline $\begin{array}{l}\text { Independent } \\
\text { Samples }\end{array}$ & -2.375 & .033 & -2.402 & .032 & -2.949 & .011 \\
\hline Test & & & & & & \\
\hline $\begin{array}{l}\text { Mann- } \\
\text { Whitney } \\
\text { Test }\end{array}$ & -1.848 & .065 & -1.901 & .057 & -1.535 & .125 \\
\hline $\begin{array}{l}\text { Two-Sample } \\
\text { Kolmogorov- } \\
\text { Smirrnov } \\
\text { Note: SDEA = }\end{array}$ & andard I & .153 & 1.512 & .021 & 1.512 & .021 \\
\hline
\end{tabular}

\section{Conclusions and Future Research}

This paper has discussed the comparison between the standard approach of DEA and the alternative approach ADEA in estimating the efficiency of Malaysian Islamic commercial banks for 2008 to 2010. In this approach, instead of using the linear averages of the input and outputs to estimate the efficiency, we use the non-linear averages of the inputs and outputs. Our results show that the estimated inefficiency score using the alternative approach are relatively smaller than those using the standard DEA approach. Further tests using the parametric and non-parametric show that as an overall, there is a significant difference using the two methods. In other words, our results show that using the alternative method relatively produces lower level of inefficiency. This is consistent to that found by Shirvani et al (2011).Since this is the first time that these two methods are employed, more sample and longer period of time is needed to prove this evidence. We suggest further research should also be carried out perhaps in other banking markets to support these findings.

\section{References}

Aik, N. C. \& Tan, K. E. (2012). Cost and profit efficiency of the full-fledged Islamic banks and Islamic window in Malaysia. Segi Review, 5(1), 41-46.

Bashir, A. H. M. (2001). Assessing the Performance of Islamic Banks: Some Evidence from the Middle East, in American Economic Association Annual Meeting, New Orleans, Louisiana.

Berger, A. N. \& Humphrey, D. B. (1997). Efficiency of Financial Institutions: International Survey and Directions for Future Research. European Journal of Operations Research, 98, 175-212 
Haron, S. W. N. \& Azmi, W. (2004). Profitability Determinants of Islamic Banks: A Co-integration Approach", Proceedings of the Islamic Banking Conference, Union Arab Bank, Beirut, Lebanon, 57December 2004

Kamaruddin, B. H., Safa, M. S. \& Mohd, R. (2008). Assessing Production Efficiency of Islamic Banks and Conventional Banks Islamic windows in Malaysia, MPRA Paper no 10670, available online at http//mpra.ub.unimuenchen.de/10670

Samad, A. \& Hassan, M. K. (1999). The Performance of Malaysian Islamic Banks during 1984-1997: An Exploratory Study. Journal of Islamic Financial Services, 1(2).

Samad, A. (2004). Performance of Interest-Free Islamic Banks Vis-a-Vis Interest-based Conventional Banks in Bahrain. IIUM Journal of Economics and Management, 12(2).

Shirvani, H., Taj, S. \& Mirshab, B. (2011). A New Approach to Data Envelopment Analysis with an Application to Bank Efficiency in Turkey. Banks and Bank Systems, 6(1), 5-10.

Sufian, F. (2007). The efficiency of Islamic banking industry in Malaysia: Foreign vs domestic banks. Humanomics, 23(3), 174-192.

Seiford, L. M. \& Thrall, R. M. (1990). Recent Developments in DEA: the Mathematical Programming Approach to Frontier Analysis. J Econometrics, 4, 7-38.

Tahir, I. M., Bakar, N. B. \& Haron, S. (2011). Evaluating Efficiency of Islamic Banks Using Data Envelopment Analysis: International Evidence. Journal of Islamic Economics, Banking and Finance, 7(1), 11-24.

\section{Appendix 1}

\section{Local Islamic banks:}

Affin Islamic Bank Bhd, Alliance Islamic Bank Bhd, AmIslamic Bank Bhd, Bank Islam Malaysia Bhd, CIMB Islamic Bank Bhd, EONCAP Islamic Bank Bhd, Hong Leong Islamic Bank Bhd, Public Islamic Bank Bhd, RHB Islamic Bank Bhd

\section{Foreign Islamic banks}

Al Rajhi Banking \& Invst. Corp. (M) Bhd, Asian Finance Bank Bhd, HSBCAmanah Malaysia Bhd, Kuwait Finance House (Malaysia) Bhd, OCBC Al-Amin Bank Bhd 